DOI: 10.32844/2222-5374-2020-104-2.29

УДК: 342.9

Мельничук Р. В.,

здобувач Національної академії внутрішніх справ

\title{
АДМІНІСТРАТИВНО-ПРАВОВЕ РЕГУЛЮВАННЯ ЗАПОБІГАННЯ КОРУПЦІЙНИМ РИЗИКАМ У ДІЯЛЬНОСТІ НАЦІОНАЛЬНОЇ ПОЛІЦІЇ УКРАЇНИ
}

Актуальність статті полягає в тому, що чинне вітчизняне законодавство вже багато років розвиває окремі аспекти тематики запобігання корупції у низці сфер життя держави та суспільства. Натомість досить логічним виглядає відсутність суттєвих позитивних результатів з означених питань, адже тотальне зловживання владними повноваженнями, непрозорість публічного управління та низка подібних потужних чинників здійснюють непереборний гальмівний процес. Така ситуація почала дієво змінюватися лише з 2014 року, коли більшість населення оцінили реальні загрози цього згубного явища, а також з'явилася реальна політична воля щодо боротьби з корупцією. Отже, наразі важливим $\epsilon$ визначення та характеристика оновленої адміністративно-правової бази з питань запобігання корупційним ризикам в діяльності Національної поліції України, що дозволить з'ясувати головне законодавче підгрунтя в окресленій сфері. Метою статті $\epsilon$ загальна характеристика адміністративноправового регулювання з питань запобігання корупційним ризикам у діяльності Національної поліції України. У статті з'ясовано та розкрито систему адміністративно-правових актів у сфері запобігання корупційним ризикам в діяльності Національної поліції України, яка включає п'ять блоків. Послідовно охарактеризовано відповідні юридичні документи, де у першому випадку мова йде про закони України «Про Національну поліцію», «Про запобігання корупції», "Про засади державної антикорупційної політики в Україні (Антикорупційна стратегія) на 2014-2017 роки», що широко ретранслюються і розвиваються у сукупності інших законодавчих актів в аналізованій сфері. Розглянуто правові акти Кабінету Міністрів України та НАЗК, які врегульовують найсуттєвіші питання реалізації державної політики у сфері запобігання корупції в публічному управлінні, зокрема в діяльності органів поліції. Окремо акцентовано на низці адміністративноправових актів МВСУкраїни та НаціональноїполіціїУкраїни, а такожзасадах притягнення працівників поліції до адміністративної та дисциплінарної відповідальності за вчинення адміністративних правопорушень, пов'язаних з корупцією.

Ключові слова: адміністративна відповідальність; декларації; запобігання корупційним ризикам; корупційні правопорушення; корупційні ризики; Національна поліція України; працівники поліцейські; правові акти. 
Актуальність теми. Чинне вітчизняне законодавство вже багато років розвиває окремі аспекти тематики запобігання корупції у низці сфер життя держави та суспільства. Натомість досить логічним виглядає відсутність суттєвих позитивних результатів 3 означених питань, адже тотальне зловживання владними повноваженнями, непрозорість публічного управління та низка подібних потужних чинників здійснюють непереборний гальмівний процес. Така ситуація почала дієво змінюватися лише з 2014 року, коли більшість населення оцінили реальні загрози цього згубного явища, а також з'явилася реальна політична воля щодо боротьби 3 корупцією. Отже, наразі важливим $€$ визначення та характеристика оновленої адміністративно-правової бази 3 питань запобігання корупційним ризикам в діяльності Національної поліції України, що дозволить з'ясувати головне законодавче підгрунтя в окресленій сфері.

Метою статті $є$ загальна характеристика адміністративно-правового регулювання з питань запобігання корупційним ризикам у діяльності Національної поліції України.

Виклад основного матеріалу. Правові акти в аналізованій сфері доречно систематизувати за певними логічними блоками функціонального призначення, які за першим із них охоплюють юридичні документи загального характеру. Першочергово мова йде про Конституцію України, Закони України «Про запобігання корупції», «Про засади державної антикорупційної політики в Україні (Антикорупційна стратегія) на 20142017 роки», «Про Національну поліцію», що більш широко ретранслюються і розвиваються у сукупності інших законодавчих актів в аналізованій сфері.

Закон України «Про центральні органи виконавчої влади» до системи центральних органів виконавчої влади відносить міністерства України та інші центральні органи виконавчої влади. Їхня діяльність грунтується на принципах верховенства права, забезпечення дотримання прав i свобод людини і громадянина, безперервності, законності, забезпечення єдності державної політики, відкритості та прозорості, відповідальності. Bci міністри мають першого заступника, та заступників, один 3 яких обов'язково є заступником з питань боротьби з корупцією.

Інші центральні органи виконавчої влади утворюються для виконання окремих функцій з реалізації державної політики як служби, агентства, інспекції, комісії. Діяльність останніх спрямовується та координується Кабінетом Міністрів України через відповідних міністрів згідно із законодавством. Прикладом, діяльність поліції - через Міністра внутрішніх справ України. Завдання цих органів $\epsilon$ [1]: надання адміністративних послуг; здійснення державного нагляду (контролю); управління об'єктами державної власності; внесення пропозицій щодо забезпечення формування державної політики на розгляд міністрів, які спрямовують та координують їх діяльність; здійснення інших завдань, визначених законами України.

Запобігання корупційним ризикам у діяльності органів виконавчої влади покладається не лише на відповідні державні структури та спеціальних суб'єктів, але й відбивається у прагненнях і бажаннях значної кількості громадян. Останні навіть без цілеспрямованої зацікавленості, лише при реалізації своїх конституційних правових 
можливостей, можуть у значній мірі позитивно впливати на зменшення корупційних ризиків.

Наведений перелік нормативно-правових актів $\epsilon$ невичерпним, однак всі інші відповідні документи тісно взаємопов'язані з певними спеціалізованими законодавчими актами 3 питань нашої тематики законами України «Про запобігання корупції» та «Про засади державної антикорупційної політики в Україні (Антикорупційна стратегія) на 20142017 роки», а також конкретизовані щодо поліції в положеннях Закону України «Про Національну поліцію» [2].

3 урахуванням специфіки поліцейської діяльності у Законі України «Про поліцію» акцентовано на окремих обмежуваних положеннях, які мають бути дотриманні при призначенні на посаду та кар'єрному просуванні по службі працівників поліції. Так, по-перше, Національна поліція наповнює та підтримує в актуальному стані бази даних, що входять до єдиної інформаційної системи МВС України, стосовно зареєстрованих кримінальних і адміністративних правопорушень, пов'язаних з корупцією, осіб, які їх учинили, та результатів розгляду цих правопорушень у судах. По-друге, для забезпечення прозорого добору та просування по службі поліцейських на підставі об'єктивного оцінювання професійного рівня та особистих якостей кожного поліцейського, відповідності їх посаді, визначення перспективи службового використання в органах поліції утворюються постійні поліцейські комісії. Повноваження члена такої комісії припиняються у разі застосування до нього заходів юридичної відповідальності за вчинення проступку, пов'язаного з корупцією.

По-третє, з метою добору осіб, здатних професійно виконувати повноваження поліції та посадові обов'язки за відповідною вакантною посадою, проводиться конкурс на службу в поліції або на зайняття вакантної посади [3]. Зауважено на тому, що у разі виявлення факту притягнення конкурсанта до відповідальності за корупційне правопорушення, він позбавляється можливості зайняти відповідну посаду.

До відповідного другого блоку входять адміністративно-правові акти Кабінету Міністрів України, які врегульовують окремі найсуттєвіші питання реалізації державної політики у сфері запобігання корупції в публічному управлінні, зокрема в діяльності органів поліції. Так, у Державній програмі щодо реалізації засад державної антикорупційної політики в Україні (Антикорупційної стратегії) на 2015-2017 роки, затвердженій постановою Кабінету Міністрів України від 29.04.2015 № 265, метою програми визначено необхідність створення ефективної загальнодержавної системи запобігання та протидії корупції на основі нових засад формування та реалізації антикорупційної політики [4]. Серед основних виконавців цих заходів визначено також МВС України, яке у межах наданих повноважень, здійснює організацію та забезпечує функціонування антикорупційних механізмів у відомстві.

У цьому сенсі, згідно з приписами Положення про Міністерство внутрішніх справ України, затвердженого постановою Кабінету Міністрів України від 28.10.2015 № 878, та розпорядження Кабінету Міністрів України від 05.10.2016 № 803-р щодо заходів із запобігання корупції в центральних органах виконавчої влади, МВС України забезпечує здійснення заходів 
щодо запобігання корупції, контроль за їх реалізацією в апараті, територіальних органах, закладах, установах і на підприємствах, що належать до сфери його управління [5]. Водночас відповідно до Положення про Національну поліцію, затвердженого постановою Кабінету Міністрів України від 28.10.2015 № 877, цей орган забезпечує здійснення заходів із запобігання корупції, порушень законності, службової дисципліни і контроль за їхньою реалізацією в центральному апараті Національної поліції України, територіальних органах, на юридичних особах, що належать до сфери її управління [6].

Окремі юридичні документи Кабінету Міністрів України регулюють процедурні питання проведення службового розслідування стосовно осіб, уповноважених на виконання функцій держави або місцевого, та проведення спеціальної перевірки стосовно осіб, які претендують на зайняття посад, які передбачають зайняття відповідального або особливо відповідального становища, та посад з підвищеним корупційним ризиком.

3 урахуванням об'єктивного стану речей, що в Україні НАЗК $\epsilon$ головним суб'єктом щодо формування та реалізації державної політики у сфері запобігання корупції, цей державний орган зі спеціальним статусом у значній мірі переважно одноосібно унормовує та розвиває базові питання відповідної діяльності. Низка наказів і рішень НАЗК закладають той адміністративно-правовий масив, який утворює третій законодавчий блок у частині організації та здійснення діяльності, пов'язаної з попередженням та протидії корупційним ризикам в діяльності Національної поліції. Варто звернутися до означених наказів, які в аналізованій нами тематиці охоплюють два ключових спрямування, по-перше в організації та контролю за діяльністю уповноважених підрозділів з питань запобігання та виявлення корупції - Управління запобігання корупції та проведення люстрації МВС України та Управління з питань запобігання корупції та проведення люстрації Національної поліції України.

Типовим положенням про уповноважений підрозділ (уповноважену особу) з питань запобігання та виявлення корупції, затвердженим наказом Національного агентства 3 питань запобігання корупції від 17.03.2020 № 102/20 визначено основні завдання таких підрозділів [7]. Також у межах своєї компетенції НАЗК проводить планові та позапланові перевірки організації роботи із запобігання і виявлення корупції в державних органах, органах влади Автономної Республіки Крим, органах місцевого самоврядування, окремих юридичних особах. Відповідно до положень Порядку проведення перевірок організації роботи із запобігання i виявлення корупції, затвердженого наказом Національного агентства 3 питань запобігання корупції від 27.05.2020 № 223/20 [8].

Однимізнайважливішихздобутківантикорупційноїреформи останніх років стало запровадження інституту декларування доходів посадовців. На сьогодні чинними є Порядок відбору декларацій осіб, уповноважених на виконання функцій держави або місцевого самоврядування, затверджений наказом Національного агентства 3 питань запобігання корупції від 05.05.2020 № 172/20 [9], та Порядок проведення контролю та повної перевірки декларації особи, уповноваженої на виконання функцій держави або місцевого самоврядування, затверджений наказом Національного агент- 
ства $з$ питань запобігання корупції від 15.04.2020 № 144/20 [10]. Наведені нормативно-правові акти визначають базові категорії у цій сфері, окреслюють порядок, загальні та спеціальні процедури відбору декларацій осіб, уповноважених на виконання функцій держави або місцевого самоврядування, проведення їхнього контролю та повної перевірки та ін.

Значним функціоналом наповнені рішення НАЗК як юридичні документи інформаційно-роз'яснювального та методичного характеру. Так, Перелік посад з високим та підвищеним рівнем корупційних ризиків, затверджений рішенням Національного агентства з питань запобігання корупції від 17.06.2016 № 2, до таких посад, зокрема відносить керівників державних підприємств, установ, організацій, а також інших суб'єктів господарювання державної форми власності та їхніх заступників, призначення яких здійснюється державними органами; посади державної служби, визначені структурою державних органів, юрисдикція яких поширюється на всю територію України, у разі недоцільності утворення структурних підрозділів [11]. Методологія оцінювання корупційних ризиків у діяльності органів влади, затверджена рішенням Національного агентства з питань запобігання корупції від 02.12.2016 № 126, визначає комплекс правил і процедур щодо оцінки корупційних ризиків у діяльності органів влади, у яких згідно з ч. 1 ст. 19 Закону України «Про запобігання корупції» приймаються антикорупційні програми.

Четвертий блок адміністративно-правових актів щодо запобігання корупційним ризикам в діяльності Національної поліціїУкраїни утворюють окремі відомчі документи. Першочергово варто вказати Антикорупційну програму Міністерства внутрішніх справ України на 2020-2022 роки, затверджену наказом МВС України від 31.01.2020 № 84, та Антикорупційну програму Національної поліції України на 2019-2021 роки, затверджену наказом голови Національної поліції України від 20.03.2019 № 246. Вони містять у собі не лише засадничі стратегічні підходи з реалізації антикорупційної державної політики у сфері компетенції відповідних правоохоронних органів, але й наводять доволі конкретний перелік планових заходів і засобів. Останні у найближчій перспективі дозволять ефективно й раціонально попереджувати і боротися з корупційними правопорушеннями серед працівників поліції, підвищити авторитетність та довіри до органів поліції серед населення.

Специфічність п'ятого блоку адміністративно-правових актів 3 питань запобігання корупційним ризикам в діяльності Національної поліції України зумовлено тим, що врегулювання будь-якої суспільної сфери вимагає ефективного функціонування юридичних механізмів протидії правопорушенням, обгрунтованого і справедливого притягнення винних осіб до відповідальності. У кінцевому підсумку рівномірно доповнюється вся система запобігання корупційним ризикам, яка спрямовується на попередження та профілактику корупційних проступків через створення необхідного стійкого службового середовища, де суттєво зниженні чи взагалі відсутні корупційні ризики для працівників поліції.

Поряд із кримінальною відповідальністю чинним правовим полем передбачено дисциплінарну та адміністративну відповідальність за порушення антикорупційного законодавства. Дисциплінарний статут 
Національної поліції України, затверджений Законом України від 15.03.2018 № 2337-VIII, визначає, що службова дисципліна - це дотримання поліцейським Конституції і законів України, міжнародних договорів, актів Президента України і Кабінету Міністрів України, наказів Національної поліції України, нормативно-правових актів МВС України, Присяги поліцейського, наказів керівників.

За іï порушення поліцейські незалежно від займаної посади та спеціального звання несуть дисциплінарну відповідальність, зокрема за вчинення адміністративних правопорушень, окрім випадків, передбачених Кодексом України про адміністративні правопорушення (КУпАП) [12]. Відповідні матеріали реалізуються згідно з приписами Порядку оформлення протоколів про адміністративні правопорушення Національним агентством 3 питань запобігання корупції, затвердженого наказом Національного агентства $з$ питань запобігання корупції від 06.12.2019 № 159/19 [13].

Дисциплінарним проступком визнається протиправна винна дія чи бездіяльність поліцейського, що полягає в порушенні ним службової дисципліни, невиконанні чи неналежному виконанні обов'язків поліцейського або виходить за їх межі, порушенні обмежень та заборон, визначених законодавством для поліцейських, а також у вчиненні дій, що підривають авторитет поліції. До поліцейських можуть застосовуватися такі види дисциплінарних стягнень: зауваження; догана; сувора догана; попередження про неповну службову відповідність; пониження у спеціальному званні на один ступінь; звільнення з посади; звільнення із служби в поліції. 3 метою об'єктивного та повного встановлення всіх обставин конкретної справи дисциплінарною комісією проводиться службове розслідування відповідно до вимог Порядку проведення службових розслідувань у Національній поліції України та Положення про дисциплінарні комісії в Національній поліції України, затверджених наказом МВС України від 07.11.2018 № 893.

Службове розслідування призначається за письмовим наказом керівника, якому надані повноваження із застосування до поліцейського дисциплінарного стягнення. Відповідне розслідування призначається, зокрема, за наявності даних про надходження подання спеціально уповноваженого суб'єкта у сфері протидії корупції або припису НАЗК, в якому міститься вимога щодо проведення службового розслідування з метою виявлення причин і умов, за яких стало можливим учинення корупційногоабопов'язаного з корупцією правопорушення чи невиконання Закону України «Про запобігання корупції» [14]. У разі підтвердження факту вчинення правопорушення, відсторонення поліцейського від виконання службових обов'язків (посади) здійснюється відповідно до зазначеного законодавчого акту.

Висновки. 3 урахуванням зазначеного вище, доцільно підсумувати, що система адміністративно-правових актів у сфері запобігання корупційним ризикам в діяльності Національної поліції України охоплює п'ять логічних блоків, які за першим із них охоплюють юридичні документи загального характеру. До другого блоку входять адміністративно-правові акти Кабінету Міністрів України, які врегульовують окремі найсуттєвіші 
питання реалізації державної політики у сфері запобігання корупції в публічному управлінні, зокрема в діяльності органів поліції.

Низка наказів і рішень НАЗК закладають той адміністративноправовий масив, який утворює третій законодавчий блок у частині організації та здійснення діяльності, пов'язаної 3 попередженням та протидії корупційним ризикам в діяльності Національноїполіції. Четвертий блок адміністративно-правових актів щодо запобігання корупційним ризикам в діяльності органів поліції утворюють окремі відомчі документи МВС України та Національної поліції України. Специфічність п’ятого блоку зумовлено тим, що врегулювання будь-якої суспільної сфери вимагає ефективного функціонування механізмів притягнення винних осіб до адміністративної та дисциплінарної відповідальності.

\section{СПИСОК ВИКОРИСТАНИХ ДЖЕРЕЛ}

1. Про центральні органи виконавчої влади : Закон України від 02.07.2015 № 580-VIII. URL: https://zakon.rada.gov.ua/laws/show/58019\#Text.

2. Про запобігання корупції : Закон України від 14.10.2014 № 1700-VII. URL: https://zakon.rada.gov.ua/laws/show/1700-18\#Text.

3. Про Національну поліцію : Закон України від 02.07.2015 № 580-VIII. URL: https://zakon.rada.gov.ua/laws/show/580-19\#Text.

4. Про затвердження Державної програми щодо реалізації засад державної антикорупційної політики в Україні (Антикорупційної стратегії) на 2015-2017 роки : постанова Кабінету Міністрів України від 29.04.2015 № 265. URL: https://zakon.rada.gov.ua/laws/show/265-2015-п\#Text.

5. Про затвердження Положення про Міністерство внутрішніх справ України : постанова Кабінету Міністрів України від 28.10.2015 № 878. URL: https://zakon.rada.gov.ua/laws/show/878-2015-п\#Text.

6. Про затвердження Положення про Національну поліцію : постанова Кабінету Міністрів України від 28.10.2015 № 877. URL: https://zakon.rada. gov.ua/laws/show/877-2015-п\#Text.

7. Про затвердження Типового положення про уповноважений підрозділ (уповноважену особу) з питань запобігання та виявлення корупції : наказ Національного агентства 3 питань запобігання корупції від 17.03.2020 № 102/20. URL: https://zakon.rada.gov.ua/laws/show/z036120\#Text.

8. Про затвердження Порядку проведення перевірок організації роботи із запобігання і виявлення корупції : наказ Національного агентства з питань запобігання корупції від 27.05.2020 № 223/20. URL: https:// zakon.rada.gov.ua/laws/show/z0520-20\#Text.

9. Про затвердження Порядку відбору декларацій осіб, уповноважених на виконання функцій держави або місцевого самоврядування, для проведення їх обов'язкової повної перевірки та визначення черговості такої перевірки на підставі оцінки ризиків : наказ Національного агентства з питань запобігання корупції від 05.05.2020 № 172/20. URL: https://nazk. gov.ua/uk/documents/.

10. Про затвердження Порядку проведення контролю та повної перевірки декларації особи, уповноваженої на виконання функцій держави 
або місцевого самоврядування : наказ Національного агентства з питань запобігання корупції від 15.04.2020 № 144/20 URL: https://zakon.rada.gov. ua/laws/show/z0362-20\#Text.

11. Про затвердження Переліку посад з високим та підвищеним рівнем корупційних ризиків : рішення Національного агентства з питань запобігання корупції від 17.06.2016 № 2. URL: https://zakon.rada.gov.ua/ laws/show/z0987-16\#Text.

12. Про Дисциплінарний статут Національної поліції України : Закон України від 15.03.2018 № 2337-VIII. URL: https://zakon.rada.gov.ua/laws/ show/2337-19\#Text.

13. Про затвердження Порядку оформлення протоколів про адміністративні правопорушення Національним агентством 3 питань запобігання корупції : наказ Національного агентства з питань запобігання корупції від 06.12.2019 № 159/19. URL: https://zakon.rada.gov.ua/laws/ show/ z0014-20\#Text.

14. Про реалізацію окремих положень Дисциплінарного статуту Національної поліції України : наказ МВС України від 07.11.2018 № 893. URL: https://zakon.rada.gov.ua/laws/show/z1355-18\#Text.

\section{R. Melnychuk}

\section{ADMINISTRATIVE AND LEGAL REGULATION OF PREVENTION OF CORRUPTION RISKS IN THE ACTIVITIES OF THE NATIONAL POLICE OF UKRAINE}

The relevance of the article is that the current domestic legislation has been developing for many years some aspects of the prevention of corruption in a number of spheres of life of the state and society. Instead, it seems quite logical that there are no significant positive results on these issues, because the total abuse of power, non-transparency of public administration and a number of such powerful factors carry out an insurmountable inhibitory process. This situation began to change effectively only in 2014, when the majority of the population assessed the real threats of this devastating phenomenon, as well as the real political will to fight corruption. Thus, it is important to define and characterize the updated administrative and legal framework for the prevention of corruption risks in the activities of the National Police of Ukraine, which will clarify the main legal basis in this area. The purpose of the article is a general description of the administrative and legal regulation on the prevention of corruption risks in the activities of the National Police of Ukraine. In the article, the system of administrative legal acts is found out and exposed in the field of prevention of corruption risks in activity of the National police of Ukraine that includes five blocks. Corresponding legal documents are consistently described, where in first case the question is about the laws of Ukraine "On the National police", "About prevention of corruption", "About principles of public anticorruption policy in Ukraine (Anticorruption strategy) on 2014-2017", that is widely retransmitted and develop in totality of other legislative acts in analysable sphere. The legal acts of Cabinet of Ministers of Ukraine and $N A C P$ are considered, that regulate the most substantial questions of realization of public policy in the field of prevention of corruption in a public management, 
in particular in activity of organs of police. It is separately accented on the row of administrative legal acts of MIA and National police of Ukraine, and also principles of bringing in of workers of police to administrative and disciplinary responsibility for the feasance of the administrative crimes related to the corruption.

Keywords: administrative responsibility; declarations; prevention of corruption risks; corruption offences; corruption risks; National police of Ukraine; workers are constabulary; legal acts. 